\title{
Pengaruh Aromaterapi Lemon terhadap Penurunan Intensitas Nyeri Post Operasi Laparatomi di Ruang Bedah RSUD Raden Mataher Jambi
}

\author{
Hasyim Kadri ${ }^{1}$, Salvita Fitrianti ${ }^{2}$ \\ ${ }^{1-2}$ Program Studi S1 Ilmu Keperawatan, Sekolah Tinggi Ilmu Kesehatan Baiturrahim Jambi \\ Email :h451mkadri87@gmail.com
}

Submitted :02 /04/2020

Accepted: 16/04/2020

Published: 7/09/2020

\begin{abstract}
Laparatomi surgery in the Raden Mattaher Jambi Hospital Operating Room in the last 3 years has increased. The average per month of Laparatomi surgery in 2017 is 31 actions, in 2018 there are 33 actions and increased to 38 actions in 2019. This research aims to look at the effect of the aroma of lemon therapy on decreasing pain intensity in post-op Laparatomi patients in the operating room Raden Mattaher Hospital in Jambi. This research is a quantitative study with a pre-experimental design without control group. Aims to see the effect of the aroma of lemon therapy on the decrease in pain intensity in post-op Laparatomi patients in the Raden Mattaher Hospital Operating Room Jambi. The population of this study was all post-op patients in the Operating Room at Raden Mattaher Jambi Hospital in the 2019 Deesember period with a total of 44 people. Samples amounted to 10 people. Accidental sampling, $t$-dependent statistical test. The results of the study on average scale pain post Laparatomi patients before being given the aroma of lemon therapy was 5.20 (moderate pain). After being given the aroma of lemon therapy, the average pain scale of the patient was 4.50 (moderate pain). The difference between the pre-test and post-test pain scales was 0.70. There is an influence of the aroma of lemon therapy on the decrease in pain intensity in post-op Laparatomi patients with a pvalue of 0.001 ( $p$ <0.05). Researchers hope at the Raden Mattaher Jambi Hospital to make the aroma of lemon therapy as an alternative that can be used to help reduce the pain felt by post-op Laparatomi patients.
\end{abstract}

Keywords: aroma therapy effect of lemon, pain relief, post operative laparotomy

\begin{abstract}
Abstrak
Tindakan operasi laparatomi di Ruang Bedah RSUD Raden Mattaher Jambi dalam 3 tahun terakhir ini mengalami peningkatan. Rata-rata per bulan operasi laparatomi pada tahun 2017 adalah sebanyak 31 tindakan, tahun 2018 sebanyak 33 tindakan dan meningkat menjadi 38 tindakan pada tahun 2019.Pemelitian ini bertujuan untuk melihat pengaruh aroma terapi lemon terhadap penurunan intensitas nyeri pada pasien post op laparatomi di Ruang Bedah RSUD Raden Mattaher Jambi.Penelitian ini penelitian kuantitatif dengan rancangan pra eksperimen without control group. Bertujuan untuk melihat pengaruh aroma terapi lemon terhadap penurunan intensitas nyeri pada pasien post op laparatomi di Ruang Bedah RSUD Raden Mattaher Jambi. Populasi penelitian ini adalah seluruh pasien post op Ruang Bedah RSUD Raden Mattaher Jambi periode Deesember 2019 dengan jumlah 44 orang. Sampel berjumlah 10 orang. Pengambilan sampel accidental sampling, uji statistik $t$-dependen. Hasil penelitian rata-rata skala nyeri pasien post op laparatomi sebelum diberikan aroma terapi lemon adalah 5,20 (nyeri sedang). Setelah diberikan aroma terapi lemon, rata-rata skala nyeri pasien adalah 4,50 (nyeri sedang). Selisih skala nyeri pre test dengan post test adalah 0,70 . Ada pengaruh aroma terapi lemon terhadap penurunan intensitas nyeri pada pasien post op laparatomi dengan p-value 0,001 ( $\mathrm{p}<0,05)$. Peneliti berharap pada pihak RSUD Raden Mattaher Jambi untuk menjadikan aroma terapi lemon sebagai suatu alternatif yang dapat digunakan untuk membantu menurunkan nyeri yang dirasakan oleh pasien post op laparatomi.
\end{abstract}

Kata kunci : efek aroma terapi lemon, nyeri, pasca operasi laparatomi 


\section{PENDAHULUAN}

Berdasarkan data yang diperoleh dari World Health Organization (WHO) dalam Sartika (2013), jumlah pasien dengan tindakan operasi mencapai angka peningkatan yang sangat signifikan dari tahun ke tahun. Tercatat di tahun 2011 terdapat 140 juta pasien di seluruh rumah sakit di dunia, sedangkan pada tahun 2012 data mengalami peningkatan sebesar 148 juta jiwa. Tindakan operasi di Indonesia pada tahun 2012 mencapai 1,2 juta jiwa.

Laparatomi merupakan salah satu prosedur pembedahan mayor, dengan melakukan penyayatan pada lapisan-lapisan dinding abdomen untuk mendapatkan bagian organ abdomen yang mengalami masalah (hemoragi, perforasi, kanker, dan obstruksi). Laparatomi juga dilakukan pada kasus-kasus digestif dan kandungan seperti apendiksitis, perforasi, hernia inguinalis, kanker lambung, kanker colon dan rectum, obstruksi usus, inflamasi usus kronis, kolestisitis dan peritonitis (Rahmayati, Hardiansyah \& Nurhayati, 2018).

Pasien pasca operasi seringkali dihadapkan pada permasalahan adanya proses peradangan akut dan nyeri yang mengakibatkan keterbatasan gerak. Nyeri bukanlah akibat sisa pembedahan yang tidak dapat dihindari tetapi ini merupakan komplikasi bermakna pada sebagian besar pasien. Akibat nyeri pasca operasi, pasien menjadi immobil yang merupakan kontraindikasi yang dapat mempengaruhi kondisi pasien. Dari segi penderita, timbulnya dan beratnya rasa nyeri pasca bedah dipengaruhi fisik, psikis atau emosi, karakter individu dan sosial kultural maupun pengalaman masa lalu terhadap rasa nyeri. Derajat kecemasan penderita pra bedah dan pasca bedah juga mempunyai peranan penting. Misalnya, takut mati, takut kehilangan kesadaran, takut akan terjadinya penyulit dari anestesi dan pembedahan, rasa takut akan rasa nyeri yang hebat setelah pembedahan selesai (Widya, 2010).
Rasa nyeri merupakan stressor yang dapat menimbulkan ketegangan. Individu akan merespon secara biologis dan perilaku yang menimbulkan respon fisik dan psikis. Respon fisik meliputi perubahan keadaan umum, ekspresi wajah, nadi, pernafasan, suhu, sikap badan dan apabila nyeri berada pada derajat berat dapat menyebabkan kolaps kardiovaskuler dan syok. Respon psikis akibat nyeri dapat merangsang respon stress yang dapat menekan sistem imun dan peradangan, serta menghambat penyembuhan. Respon yang lebih parah akan mengarah pada ancaman merusak diri. Nyeri pada pasien dapat terjadi karena proses perjalanan penyakit maupun tindakan diagnostik dan invasif pada pemeriksaan (Smeltzer \& Bare, 2013).

Penatalaksanaan nyeri dapat dilakukan dengan teknik farmakologi dan non farmakologi. Teknik farmakologi adalah penanganan nyeri dengan menggunakan obat-obatan nyeri sedangkan teknik non farmakologi adalah penanganan nyeri dengan tidak menggunakan obatobatan seperti relaksasi, distraksi, massage, guided imaginary dan aromaterapi. Salah satu aromaterapi yang bisa digunakan adalah aromaterapi lemon, untuk menurunkan intensitas nyeri pasien post operasi laparatomi (Rahmayati, Hardiansyah \& Nurhayati, 2018).

Aromaterapi adalah suatu metode dalam relaksasi yang menggunakan minyak esensial atau uap dalam pelaksanaannya berguna untuk meningkatkan kesehatan fisik, emosi, dan spirit seseorang. Aromaterapi lemon merupakan jenis aromaterapi yang dapat digunakan untuk mengatasi nyeri dan cemas (Narrilawati, 2015).

Bau berpengaruh langsung terhadap otak manusia, seperti narkotika. Hidung memiliki kemampuan untuk membedakan lebih dari 100.000 bau yang berbeda yang mempengaruhi manusia tanpa disadari. Bau-bauan tersebut masuk kehidung dan 
berhubungan dengan silia. Reseptor di silia mengubah bau tersebut menjadi impuls listrik yang di pancarkan ke otak dan mempengaruhi bagian otak yang berkaitan dengan mood (suasana hati), emosi, ingatan, dan pembelajaran (Purwandari \& Sabrian, 2012).

Berdasarkan data di ruangan Bedah Rumah Sakit Umum Daerah Raden Mattaher Jambi pada tanggal 24 April 2019 sampai tanggal 02 Mei 2019 jumlah pasien dengan post operasi laparatomi E.C Abses Hepar adalah 13 orang.

Penelitian yang dilakukan oleh Cholifah, Raden \& Ismarwati (2016) dengan judul "Pengaruh Aromaterapi Inhalasi Lemon Terhadap Penurunan Skala Nyeri Persalinan Kala 1 Fase Aktif". Desain penelitian yang digunakan adalah Quasi Experiment dengan teknik pre-test post-test non equivalent control group design. Hasil penelitian rata-rata nyeri persalinan pada kelompok yang diberikan aromaterapi lebih rendah 4,74 $\pm 1,327$ dibandingkan kelompok kontrol 5,79 $\pm 1,316$. Hasil uji Mann-Whitney $p$ $0,001<0,05$. Variabel luar berpengaruh terhadap nyeri persalinan adalah kecemasan dengan nilai $p<0.05$. Aromaterapi inhalasi lemon dapat menurunkan nyeri kala 1 fase aktif.

Berdasarkan survei awal yang dilakukan oleh penulis tanggal 22 Juli 2019 di ruang Bedah laki-laki RSUD Raden Mattaher Jambi melalui wawancara 5 orang pasien dengan post operasi laparatomi hari ke 1 didapatkan hasil 3 dari 5 dengan skala nyeri 6 dan meningkat pada saat bergerak atau beraktivitas. 2 dari 5 dengan skala nyeri 4 dan meningkat pada saat bergerak atau beraktivitas. Dan 5 orang pasien mengatakan belum pernah dengar kalau arimaterapi lemon bisa mengurangi rasa sakit.

\section{METODE PENELITIAN}

Penelitian ini merupakan penelitian kuantitatif dengan rancangan pra eksperimen without control group (tanpa kelompok kontrol). Penelitian ini dilakukan di Ruang Bedah RSUD Raden Mattaher Jambi pada tahun 2019. Sampel berjumlah 10 orang. Tehnik pengambilan accidental sampling. Metode pengumpulan data adalah dengan melakukan wawancara menggunakan kuesioner Numeric Rating Scale (NSR) untuk mengetahui intensitas/skala nyeri pasien. Metode analisis data univariat dan bivariat dangan tingkat kemaknaan 95\% (alpa 0,05) dengan menggunakan uji statistik t-dependen. Hasil penelitian dikatakan berhubungan jika $\mathrm{p}$ value $\leq 0,05$ dan dikatakan tidak berhubungan jika p value $>0,05$.

\section{HASIL DAN PEMBAHASAN}

\section{A. Rata-rata Skala Nyeri Sebelum dan Sesudah Diberikan Aroma Terapi Lemon}

Berdasarkan hasil penelitian yang telah dilakukan dapat diketahui rata-rata skala nyeri pasien post op laparatomi di Ruang Bedah RSUD Raden Mattaher Jambi sebelum dan sesudah diberikan aroma terapi lemon :

\begin{tabular}{lccccc}
$\begin{array}{c}\text { Rata-Rata } \\
\text { Skala } \\
\text { Nyeri }\end{array}$ & $\begin{array}{c}\text { Mea } \\
\text { n }\end{array}$ & $\begin{array}{c}\text { Std. } \\
\text { Eror }\end{array}$ & SD & $\begin{array}{c}\text { Mi } \\
\text { n }\end{array}$ & $\begin{array}{c}\text { Ma } \\
\mathbf{x}\end{array}$ \\
\hline Pre Test & 5,20 & 0,249 & 0,781 & 4 & 6 \\
Post Test & 4,50 & 0,373 & 1,179 & 3 & 6 \\
\hline
\end{tabular}

Hasil analisi sebelum diberikan aroma terapi lemon adalah 5,20, standar eror 0,249 , standar deviasi 0,781. Adapun skala nyeri terendah adalah 4 dan tertinggi skala nyeri 6. Setelah diberikan aroma terapi lemon, rata-rata skala nyeri pasien adalah 4,50, standar eror 0,373 , standar deviasi 1,179. Adapun skala nyeri terendah adalah 3 dan tertinggi skala nyeri 6 . Selisih skala nyeri pre test dengan post test adalah 0,70. Hal ini berarti rata-rata skala nyeri post test lebih rendah daripada skala nyeri pre test. 
Hasil penelitian ini sejalan dengan penelitian Rahmayati (2018) yang mendapati rata-rata skala nyeri pasien post op laparatomi sebelum diberikan aroma terapi lemon adalah 5,25 (nyeri sedang). Skala nyeri terendah adalah 4 dan nyeri tertinggi adalah 6. Sesudah diberikan aroma terapi lemon rata-rata skala nyeri adalah 4,00 (nyeri sedang). Skala nyeri terendah adalah 3 dan nyeri tertinggi adalah 6. Selanjutnya penelitian Purwandari (2015) juga menemukan hasil rata-rata skala nyeri pasien post op laparatomi sebelum diberikan aroma terapi lemon adalah 5,07 (nyeri sedang). Skala nyeri terendah adalah 3 dan nyeri tertinggi adalah 6. Sesudah diberikan aroma terapi lemon, rata-rata skala nyeri adalah 4,07 (nyeri sedang). Skala nyeri terendah adalah 3 dan nyeri tertinggi adalah 6 .

Nyeri merupakan pengalaman sensori dan emosi yang tidak menyenangkan akibat adanya kerusakan jaringan yang aktual atau potensial, digambarkan dengan istilah seperti (international association for the study of pain ) yaitu awitan berat yang tiba - tiba atau perlahan dengan intensitas ringan sampai berat dengan akhir yang dapat di antisipasi atau diramalkan (Wilkinson, 2014). Menurut Wong (2010), nyeri adalah keluhan tersering pada pasien setalah mengalami pembedahan. Nyeri yang dialami pasien post operasi muncul disebabkan rangsangan mekanik luka yang menyebabkan tubuh menghasilkan mediator-mediator kimia nyeri sehingga muncul nyeri pada setiap pasien post operasi.

Berdasarkan analisis kuesioner pre test yang dilakukan oleh peneliti dapat diketahui bahwa dai 10 responden, hanya $20 \%$ responden yang mengalami nyeri dengan skala 4 (sedang) dan sisanya $40 \%$ mengalami nyeri dengan skala 5 (sedang), $40 \%$ mengalami nyeri dengan skala 6 (sedang). Jadi dapat disimpulkan bahwa pada saat pre test $100 \%$ responden mengalami nyeri sedang.

Selanjutnya berdasarkan analisis kuesioner post test yang dilakukan oleh peneliti dapat diketahui bahwa dai 10 responden, hanya $30 \%$ responden yang mengalami nyeri dengan skala 6 (sedang) dan sisanya $10 \%$ mengalami nyeri dengan skala 5 (sedang), 40\% mengalami nyeri dengan skala 4 (sedang) dan telah terdapat $20 \%$ responden dengan skala nyeri 3 (ringan). Hal ini berarti bahwa telah terjadi perubahan penurunan skala nyeri pada pasien dari penatalaksanaan yang telah dilakukan oleh peneliti.

\section{B. Pengaruh Aroma Terapi Lemon terhadap Penurunan Intensitas Nyeri pada Pasien Post Op Laparatomi}

Berdasarkan hasil penelitian yang telah dilakukan dapat diketahui pengaruh aroma terapi lemon terhadap penurunan intensitas nyeri pada pasien post op laparatomi di Ruang Bedah RSUD Raden Mattaher Jambi :

\begin{tabular}{cccccc}
$\begin{array}{c}\text { Pengaruh Aroma } \\
\text { Terapi Lemon }\end{array}$ & $\begin{array}{c}\text { Mea } \\
\mathrm{n}\end{array}$ & SD & & $\begin{array}{c}\mathrm{p} \\
\text { value }\end{array}$ & $\mathrm{n}$ \\
\hline $\begin{array}{c}\text { Pre Test } \\
\text { Post Test }\end{array}$ & 5,20 & 0,789 & 0,001 & 10 \\
\hline
\end{tabular}

Hasil analisis uji chi square dapat diketahui bahwa dari 10 responden, mean post test lebih rendah dari mean pre test (mean pre test 5,20 dengan standar deviasi 0,789 dan mean post test 4,50 dengan standar deviasi 1,179). Hasil uji statistik yang dilakukan dengan menggunakan uji $\mathrm{t}$ dependen (paired sample t test) didapatkan $\mathrm{p}$-value $=0,001(\mathrm{p}$-value $<0,05)$. Hal ini dapat disimpulkan bahwa ada pengaruh yang signifikan dari aroma terapi lemon terhadap penurunan intensitas nyeri pada pasien post op laparatomi.

Hasil penelitian ini sejalan dengan penelitian Rahmayati (2018) yang mendapati hasil ada pengaruh aromaterapi lemon terhadap penurunan skala nyeri pasien post operasi laparatomi dengan $\mathrm{p}$ value 0,000 . Selanjutnya penelitian 
Purwandari (2015) juga menemukan hasil adanya pengaruh terapi aroma lemon terhadap penurunan skala nyeri pada pasien post laparatomi dengan p-value 0,000 .

Laparatomi merupakan salah satu pembedahan mayor dengan melakukan penyayatan pada lapisan lapisan dinding abdomen untuk mendapatkan bagian organ yang mengalami masalah (hemoragi, perforasi, kanker dan obstruksi), membuka selaput abdomen dengan operasi yang dilakukan untuk memeriksa organ organ abdomen dan membantu diagnosis masalah termasuk penyembuhan penyakit pada bagian abdomen (Andarmoyo, 2013).

Nyeri adalah keluhan tersering pada pasien setalah mengalami pembedahan. Nyeri yang dialami pasien post operasi muncul disebabkan rangsangan mekanik luka yang menyebabkan tubuh menghasilkan mediator-mediator kimia nyeri sehingga muncul nyeri pada setiap pasien post operasi (Wong, 2010).

Aroma terapi lemon merupakan penggunaan ekstrak minyak esensial tumbuhan lemon. Aroma terapi lemon merupakan suatu metode yang dapat meningkatkan kesehatan fisik dan juga mempengaruhi kesehatan emosi seseorang. Aroma terapi lemon merupakan minyak alami yang diambil dari tanaman aromatik lemon (Koensoemardiyah, 2009). Hal ini berarti bahwa aroma terapi lemon merupakan metode pengobatan nyeri yang di dalam nya terkandung zat alami.

Zat yang terkandung dalam lemon salah satunya adalah linalool yang berguna untuk menstabilkan sistem saraf sehingga dapat menimbulkan efek tenang bagi siapapun yang menghirupnya (Wong, 2010). Menurut Muchtaridi \& Mulyono (2015), linalool yang dapat meningkatkan sirkulasi dan menghantarkan pesan elektrokimia ke susunan saraf pusat. Selanjutnya linalool ini akan menyebabkan spasmolitik serta menurunkan aliran impuls saraf yang mentransmisikan nyeri.
Mekanisme kerja aroma terapi lemon dalam tubuh manusia berlangsung melalui dua sistem fisiologis, yaitu sirkulasi tubuh dan sistem penciuman. Wewangian dapat mempengaruhi kondisi psikis, daya ingat dan emosi seseorang. Aroma terapi lemon merupakan jenis aromaterapi yang dapat digunakan untuk mengatasi nyeri (Rahmawati, 2015).

Aromaterapi yang dihirup akan di transferkan kepusat penciuman yang berada pada pangkal otak. Pada tempat ini sel neutron akan menafsirkan bau tersebut dan akan mengantarkan ke sistem limbik. Dari sistem limbik pesan tersebut akan dihantarkan ke hipotalamus, di hipotalamus seluruh sistem minyak esensial tersebut akan diantar oleh system sirkulasi dan agen kimia kepada tubuh yang nyeri (Setyoadi, 2011).

Berdasarkan temuan tersebit, maka peneliti berharap pada perawat untuk memberikan aroma terapi lemon sebagai altenatif pendamping dalam mengatasi nyeri yang sedang dialami pasien di ruangan. Selanjutnya diharapkan juga pihak perawat dapat memberikan materi aroma terapi lemon ini pada pasien dan keluarga saat pasien akan ke luar dari rumah sakit, sehingga metode ini dapat diterapkan oleh pasien di rumahnya.

\section{SIMPULAN}

Berdasarkan hasil penelitian maka dapat dipaparkan kesimpulan dan saran yang diberikan oleh peneliti kepada pihakpihak yang terkait dalam penelitian. Adapun penjelasannya sebagai berikut : Rata-rata skala nyeri Pada pasien post op laparatomi sebelum diberikan aroma terapi lemon adalah 5,20. Setelah diberikan aroma terapi lemon, rata-rata skala nyeri pasien adalah 4,50 . Selisih skala nyeri pre test dengan post test adalah 0,70. Ada pengaruh aroma terapi lemon terhadap penurunan intensitas nyeri pada pasien post op laparatomi di Ruang Bedah RSUD Raden 
Mattaher Jambi dengan $\mathrm{p}=$ value $0,001(\mathrm{p}<$ $0,05)$.

Disarankan pada pihak RSUD Raden Mattaher Jambi untuk menjadikan aroma terapi lemon sebagai suatu alternatif yang dapat digunakan untuk membantu menurunkan nyeri yang dirasakan oleh pasien post op laparatomi.

\section{DAFTAR PUSTAKA}

Andarmoyo. (2013). Konsep dan Proses Keperawatan Nyeri. Ar-Ruzz Media. Yogyakarta

Depkes RI (2015). Anastesi Pasien Operasi di Rumah Sakit Jakarta

Dinkes Provinsi Jambi. (2018). Profil Kesehatan Provinsi Jambi. Jambi

Fahlevie, E.R. (2017). Tatalaksana Anestesi dan Reanimasi Pada Operasi Laparotomi. SMF Universitas Udayana. Denpasar

Jaelani. (2015). Manfaat Minyak Esensial Lemon. Rineka Cipta. Jakarta

Kemenkes RI. (2015). Rencana Strategis Kementerian Kesehatan Tahun 20152019. Jakarta

Kemenkes RI. (2016). Profil Kesehatan Indonesia. Jakarta

Kemenkes RI. (2018). Profil Kesehatan Indonesia. Jakarta

Koensoemardiyah. (2009). Aroma Terapi untuk Kesehatan, Kebugaran dan Kecantikan. Lily Publisher. Yogyakarta.

Mardana, I.K.R.P. \& Aryasa, T. (2017). Penilaian Nyeri. SMF Terapi Intensif. Universitas Udayana. Denpasar

Muaris, H.J. (2013). Khasiat Lemon untuk Kestabilan Kesehatan. PT Gramedia Pustaka Utama. Jakarta

Muchtaridi \& Mulyono (2015). Aroma Terapi : Tinjauan Aspek Kimia Medisinal. Graha Ilmu. Yogyakarta

Ningrum, T.P. (2017). Penatalaksanaan Wound Dehiscence pada Pasien Post Laparatomi. Nuha Medika. Yogyakarta
Purwandari, F. (2015). Efektifitas Terapi Aroma Lemon terhadap Penurunan Skala Nyeri Pada Pasien Post Laparatomi. Jurnal Ners. 4(2), 456467

Rahmayati, E. (2018). Pengaruh Aromaterapi Lemon terhadap Penurunan Skala Nyeri Pasien Post Operasi Laparatomi. Jurnal Keperawatan. 9(3), 427-432

RSUD Raden Mattaher Jambi (2019). Tindakan Operasi di Ruang Bedah RSUD Raden Mattaher. Jambi

Smeltzer \& Bare (2013). Buku Ajar Keperawatan Medikal Bedah. Alih bahasa Agung Waluyo. Edisi 8. EGC. Jakarta

Sugiyono. (2013). Metode Penelitian Kuantitatif Kualitatif. Alfabeta. Bandung

Suhada, M. (2019). Perawatan Luka Pasien Post Operasi. Nuha Medika. Yogyakarta

Suwanti, S. (2018). Pengaruh Aromaterapi Lemon (Cytrus) terhadap Penurunan Nyeri Menstruasi pada Mahasiswi di Universitas Respati Yogyakarta. Jurnal Keperawatan Respati Yogyakarta. 5(1), 345-349

Swandari, P. (2014). Terapi Herbal untuk Mengatasi Nyeri Operasi. Rineka Cipta Jakata

Utami, S. (2016). Aromaterapi Bitter Orange Sebagai Metode Anti Nyeri. EGC. Jakarta

Wilkinson, J.M. (2014). Buku Saku Diagnosa Keperawatan. Edisi 9. EGC. Jakarta

Wong D. L. (2010). Buku Ajar Keperawatan. Alih bahasa Sunarno, Agus dkk. Edisi 6 Volume 1. EGC. Jakarta

World Health Organization (WHO) (2018) - Surgical Care at the District Hospital. Switzerland

Yurisa, W. (2018). Etika Penelitian Kesehatan. Nuha Medika. Yogyakarta 